\title{
The Benthic Trophic Corner Stone Compartment in POPs Transfer from Abiotic Environment to Higher Trophic Levels-Trichoptera and Ephemeroptera Pre-Alert Indicator Role
}

\author{
Angela Curtean-Bănăduc ${ }^{\dagger}$, Alexandru Burcea ${ }^{+}(\mathbb{D}$, Claudia-Maria Mihuţ $(\mathbb{D}$ and Doru Bănăduc *(D) \\ Applied Ecology Research Center, Lucian Blaga University of Sibiu, RO-550012 Sibiu, Romania; \\ angela.banaduc@ulbsibiu.ro (A.C.-B.); alexandru.burcea@ulbsibiu.ro (A.B.); claudia.mihut@ulbsibiu.ro (C.-M.M.) \\ * Correspondence: ad.banaduc@yahoo.com \\ + The first and the second authors contributions are equal.
}

check for updates

Citation: Curtean-Bănăduc, A.; Burcea, A.; Mihuț, C.-M.; Bănăduc, D. The Benthic Trophic Corner Stone Compartment in POPs Transfer from Abiotic Environment to Higher Trophic Levels-Trichoptera and Ephemeroptera Pre-Alert Indicator Role. Water 2021, 13, 1778. https:// doi.org/10.3390/w13131778

Academic Editor: Sophia Barinova

Received: 26 April 2021

Accepted: 23 June 2021

Published: 27 June 2021

Publisher's Note: MDPI stays neutral with regard to jurisdictional claims in published maps and institutional affiliations.

Copyright: (C) 2021 by the authors Licensee MDPI, Basel, Switzerland. This article is an open access article distributed under the terms and conditions of the Creative Commons Attribution (CC BY) license (https:// creativecommons.org/licenses/by/ $4.0 /)$.

\begin{abstract}
Persistent organic pollutants (POPs) have been at the forefront of environmental contamination research even before their ban in 2001 at the Stockholm Convention. Their relation to different compartments of the environment (biotic and abiotic) has been thoroughly investigated. This article aims to identify whether the benthos could represent a reliable indicator of environmental contamination with POPs and to highlight its potential transfer role between abiotic and upper trophic compartments-benthos feeders. In this regard, we determined that the Ephemeroptera samples have higher concentrations $(p<0.05)$ of $\Sigma \mathrm{PCB}, \Sigma \mathrm{HCH}$, and $\Sigma \mathrm{DDT}$ than sediment samples while Trichoptera samples have higher concentrations $(p<0.05)$ only in the case of $\Sigma$ PCB and $\Sigma D D T$. This, along with the fact that the frequency of detection for POPs is similar between the sample types (sediments, Trichoptera, and Ephemeroptera), makes the benthos samples valuable indicators of contamination with sediment samples working as complementary information about how recent the contamination is.
\end{abstract}

Keywords: lotic ecosystem; organochlorine pesticides; polychlorinated biphenyls; sediments; benthos

\section{Introduction}

In spite of the fact that in the Lower Danube Basin the footprints of Homo sapiens actions date back to $180,000 \mathrm{BC}$, and over time the adverse effects of these activities on habitats and biodiversity have become more and more aggressive and complicated [1-7], the human-dominated management of streams and rivers in the Anthropocene is not impossible if the management approach is integrated and adapted on-site [8-10]. One of the main second-order tributaries of the Danube River is the Mureş River, its upper and middle watershed being placed in the amphitheater-shape Transylvanian Depression, ringed by the South-Eastern Carpathians, and inhabited by over seven million people [11]; it is a space with variable and important human impact [12-15]. The different types of human impact presence here are more or less addressed by scientific studies; however, studies on the presence and effects of the xenobiotic chemical compounds, namely persistent organic pollutants (POPs) [16], a relatively new threat around the globe [17], in the studied area on aquatic life and their environment are scarce.

POPs, which were recognized as one of the main threats due to their toxicity and diverse environmental and human health risks [18], are mainly manmade composite substances characterized by high resistance to photolytic, chemic, biologic, and mechanic deterioration [19-21]. Being volatile, POPs are carried through air at far-reaching distances from the emission sources [22]; moreover, POPs pollute lotic systems by the way of groundwater or by direct discharge [18,23] and are accumulated in sediment [24], which plays a major role in the water quality of rivers and the quality of biota $[4,25,26]$, adsorbed in suspended particles and on/into the aquatic organisms [27-29]. Owing to the hydrophobic 
nature of POPs, they concentrate in the sediment, thus changing this abiotic compartment into a pool for pollutants $[24,27,30]$. This is the argument for why sediment is the main source of POPs and a risk to the benthic organisms [31,32] that bioaccumulate them throughout their lifecycle by simple contact with sediment and water, and through food intake [33]. The contamination with POPs is granted an unequivocal mechanism due to their hydrophobic quality and reciprocal action of sediment with benthic organisms, considered to be the principal hazard path [29]. Through the feeding on insect larvae by higher food trophic net organisms, POPs begin to bioconcentrate from one level to another $[33,34]$. It is accepted that POPs bioaccumulate in the animals' fatty tissues because of their lipophilic nature [18], including in edible organisms such as fish [35,36]. We suggest that as a rationale effect, the trophic niches created by benthic organisms represent a compartment with a functional-transfer role of POPs between the abiotic and higher-level trophic compartments ending on the human plates, the insect larvae representing, due to their relatively high biomass and turn-over, a very important taxonomic group for the circulation of POPs in nature.

Until their ban in 2001 through the Stockholm Convention [18], POPs were considered a success in the field of insecticide use. This was the case for organochlorine pesticides (OCPs), in the electric industry, and polychlorobiphenyls (PCBs). Because of their long period of use, POPs became ubiquitous compounds in air, water, and soil [34,37]. Due to this, POPs were deemed to be a major threat, while the research in this field has acknowledged their impact and secondary negative effects on the environment and on human health [38-42]. It has been determined that the presence of POPs in the environment leads to its degradation which in turn affects the health and integrity of every organism through body anomalies, physiological imbalances, disturbances in sex ratios, impaired reproduction, low fertility, and cancer [39,42].

In this study, we focused on the benthic functional compartment, namely certain components: the insect larvae from Trichoptera and Ephemeroptera orders as these organisms are common in the trophic nets of benthic lotic habitats. Trichoptera and Ephemeroptera are representative in the studied area and have long been considered as water pollution indicators $[43,44]$; they have been used as indicators of environmental contamination with trace elements $[45,46]$. Furthermore, insects are considered to be one of the main groups used in biodiversity studies due to their high individual and taxonomic group count and their complexity [47]. Their importance is derived from their trophic net position, being the link between collectors of organic matter from the substrate, filter feeders, herbivores, detritivores, and predators $[48,49]$. It can also be noted that functional feeding groups (FFGs) can influence contaminant accumulation [50] due to their preferred feeding style.

All Trichoptera species are found in freshwater on every continent except Antarctica [51]. Trichoptera can be used to obtain information about pollution because they are susceptible to environmental changes. The capacity of their larvae to accumulate and bioamplify POPs from the sediments can be used to indicate the presence and level of pollution. In the larval stage, Trichoptera species are aquatic and benthic with a period of two months to two years of development. Because of this long larval stage, the larger part of the nutrients gathered by the individual occurs during this period. Trichoptera larvae, depending on the species, are designed as different types of feeders, such as collectors of organic materials from the substrate, filter feeders, herbivores, detritivores, or predators. Because collecting feeders concentrate the organic matter inside their bodies and because the diversity and number of individuals of this group are high, they constitute the main source of nutrients for other aquatic organisms [51,52].

The food demands for the species of the Ephemeroptera are similar to those of the Trichoptera. Ephemeroptera species also can be used to obtain data about pollution because they are susceptible to such environmental modifications. Their larvae capacity to accumulate and bioamplify POPs from the sediments can be used to indicate the presence and level of pollution. The lack of certain species can offer information about the nature of pollution if the characteristics of the pollutants are known [53,54]. This can be further expanded 
upon when considering that studies involving sediment samples can be accompanied by studies that identify benthos contamination with POPs for a better understanding of the underlining processes. The individuals from this order can have a larval period of up to two years and are found in aquatic habitats around the globe, with the exception of the Antarctic [55]. Most species from the Ephemeroptera order are collecting and grazing feeders and can even consume detritus [56,57].

Based on a few key studies [32,58], it has been reported that bottom surface sediment samples confer good data with regards to river environment pollution, being a good indicator of pollutants.

The aim of our study was to determine if Trichoptera and Ephemeroptera larvae can be good indicators of habitat contamination with POPs because of their already established role in water quality assessment for other bioaccumulating types of pollutants [36] and negatively influence in time the fish [59-65] traditionally used as food by humans in the studied area [66-68]. We expected that these indicators, through their bioaccumulation and bioamplification capacity, can reveal the aquatic ecosystem contamination with POPs. The advantage of working with these larvae is that they are relatively easy to be sampled, and because of their relatively low mobility, they offer the chance to relate the results of POP contamination to specific river sectors.

\section{Materials and Methods}

\subsection{Study Area and Sample Collection}

The Mureş River is the largest tributary of the Tisza River, constituting an important sub-basin of the Danube Basin, with a total length of $716 \mathrm{~km}$ and a multiannual flow of $177 \mathrm{~m}^{3} \mathrm{~s}^{-1}$, in the Romanian segment [69]. The Mureş River basin contains over seven million people and accumulates the majority of the human communities' pollutants [11,12]. The origins here of potential POPs pollution are the chemical industry, intensive livestock farms, waste warehouses, water treatment plants, metallurgical factories, electrical transformer plant facilities, etc. [70].

Sediment, Ephemeroptera, and Trichoptera samples were collected on 7-16 August 2016 from the following sampling sites: M1, M2, M3, M4, M6, M7, M11, M12, and M14 on the Mureș River (Figure 1).

The establishment of the sampling stations was based on the following criteria: the presence of point sources of pollution with POPs (industrial sources, landfills, wastewater treatment plants, untreated municipal wastewater discharges, direct discharges of industrial wastewater, animal husbandry pollution sources); areas with intensive agriculture; areas with high density of domestic animals.

M1-645 m altitude, average width of the minor riverbed $25 \mathrm{~m}$ (max. $30 \mathrm{~m}, \mathrm{~min} .20 \mathrm{~m}$ ). The river has a mountainous appearance, with a slope in the center of the riverbed; the substratum consists of boulders and medium-sized stones; gravel and sandy areas appear toward the banks. There is a strand of willows on the banks. The benthic macroinvertebrate community consists of Ephemeroptera (39.41\%), Plecoptera (25.29\%), Trichoptera (12.94\%), Amphipoda (7.06\%), Planaridae (6.47\%), Gastropoda (4.12\%, Ancylus fluviatilis), Chironomidae $(4.71 \%)$.

M2-358 $\mathrm{m}$ altitude, average width of the minor riverbed $90 \mathrm{~m}$ (max. $110 \mathrm{~m}$, $\mathrm{min} .70 \mathrm{~m})$, linear flow, relatively uniform. The substrate consists predominantly of medium-sized stones, boulders appear in the center of the riverbed, and toward the banks is gravel covered with bioderm and the presence of sandy surfaces. Riparian vegetation consists of willows. The benthic macroinvertebrate community consists of Ephemeroptera (36.28\%), Trichoptera (28.84\%), Chironomidae (14.88\%), Oligochaeta (13.49\%), Planaridae (4.19\%), Gastropoda (2.32\%, Ancylus fluviatilis).

With an M3-294 $\mathrm{m}$ altitude, an average width of the minor riverbed of $40 \mathrm{~m}$ (max. $60 \mathrm{~m}$, min. $30 \mathrm{~m}$ ) and a linear flow with ups and downs, the substratum consists mainly of medium stones on a bed of sand and mud. In the center of the riverbed are boulders in some places, and on the banks, there are surfaces with gravel and sand. The left bank 
has grassy vegetation, and on the right bank, there is a strip of willows. The benthic macroinvertebrate community consists of Ephemeroptera (50.91\%), Trichoptera (29.09\%), Chironomidae (10.30\%), Oligochaeta (7.27\%), and Blepharoceridae (2.43\%).

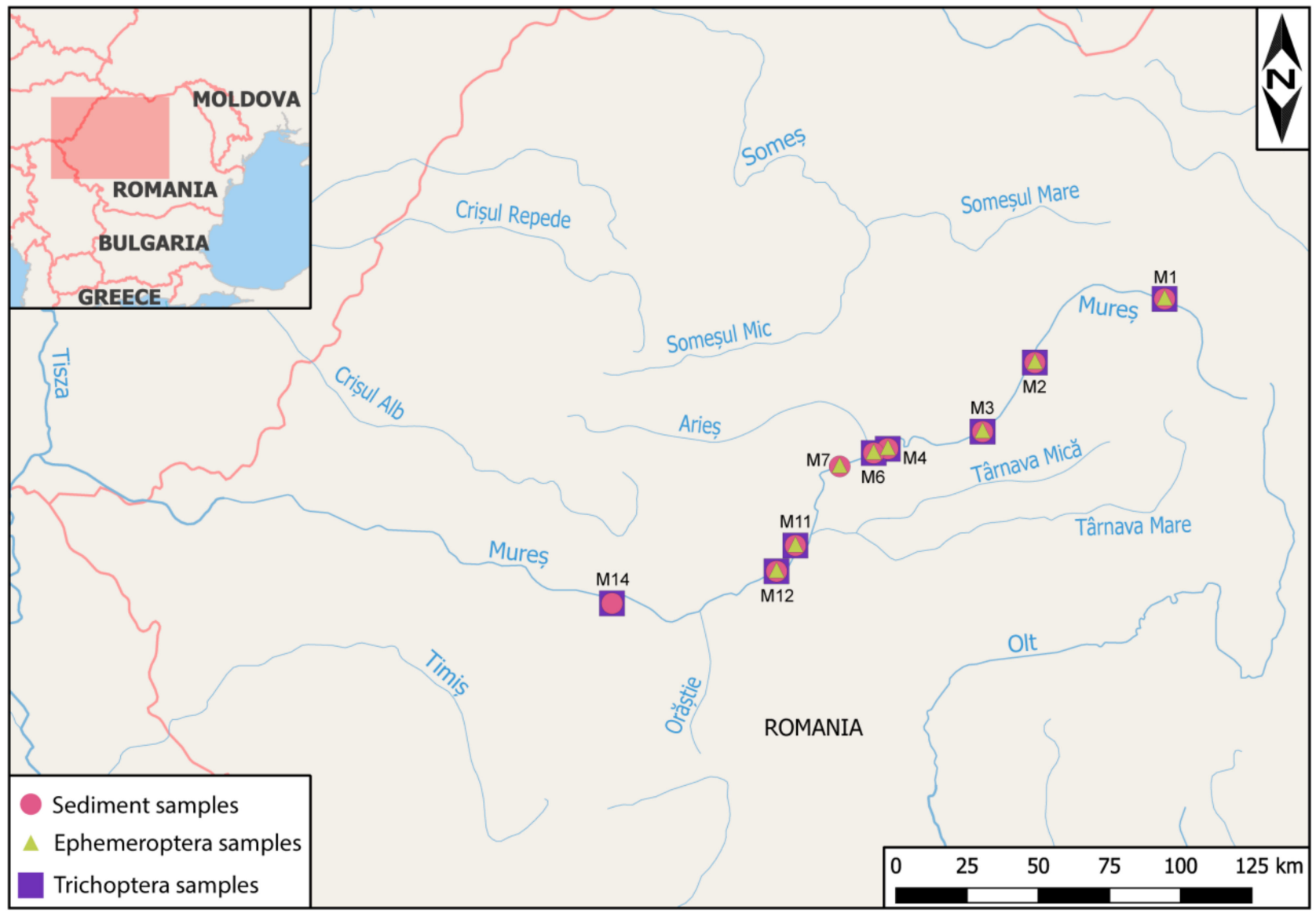

Figure 1. The sample sites with geographical coordinates are: M1 (46 94567-025 29396), M2 (46 $73324-024$ 70280), M3 (46 50931-024 47209), M4 (46 44489-024 04081), M6 (46 42958-023 97672), M7 (46 38317-023 82367), M11 (46 $38317-023$ 82367), M12 (46 04262-023 55594), M14 (45 91626-022 81669).

M4-277 m altitude, average width of the minor riverbed $60 \mathrm{~m}$ (max. $80 \mathrm{~m}$, min. $40 \mathrm{~m}$ ), slower linear flow, with unraveling, the substrate consists of mud, clay, fine sand, and toward the center of the riverbed there are surfaces with small, medium, and large stones (marls) on the muddy bed. The banks are steep; on the bank, there is grassy vegetation, and on the right bank, there are willows. The benthic macroinvertebrate community consists of Trichoptera (30.88\%), Ephemeroptera (28.57\%), Planaridae $(18.89 \%)$, Chironomidae (11.52\%), Oligochaeta (9.68\%), Bivalvia ( $0.46 \%$, Sinanodnta woodiana).

M6-268 m altitude, average width of the minor riverbed $65 \mathrm{~m}$ (max. $85 \mathrm{~m}$, min. $45 \mathrm{~m}$ ), slower smooth flow; in the riverbed, there is a bottom threshold, and the substrate is formed of large and medium stones on mud bed. The course is meandering and the riparian vegetation is grassy, but willows also appear in certain places. The benthic macroinvertebrate community is formed of Ephemeroptera (34.31\%), Planaridae (20.59\%), Trichoptera (19.61\%), Chironomidae (15.69\%), Oligochaeta (9.80\%).

M7-259 m altitude, average width of the minor riverbed $65 \mathrm{~m}$ (max. $85 \mathrm{~m}, \min .45 \mathrm{~m}$ ), the substratum consists of gravel on a bed of sand, and on the banks, there is grassy vegetation and willows. The benthic macroinvertebrate community consists of Ephemeroptera $(40.71 \%)$, Chironomidae $(30.71 \%)$, Oligochaeta $(22.14 \%)$, Trichoptera $(5 \%)$, Planaridae $(0.72 \%)$, Gastropoda $(0.72 \%$, Ancylus fluviatilis).

M11-278 m altitude, average width of the minor riverbed $70 \mathrm{~m}$ (max. $90 \mathrm{~m}$, $\min .50 \mathrm{~m}$ ), the substrate consists predominantly of gravel on a bed of sand and mud, and sandy 
surfaces appear on the banks. The benthic macroinvertebrate community consists of Trichoptera (25.0\%), Chironomidae (24.40\%), Ephemeroptera (21.39\%), Oligochaeta (20.48\%), Amphipoda (5.72\%), Tipulidae (2.11\%), Gastropoda (0.90\%, Physella acuta).

M12-218 $\mathrm{m}$ altitude, average width of the minor riverbed $75 \mathrm{~m}$ (max. $95 \mathrm{~m}, \mathrm{~min} .55 \mathrm{~m})$, the substrate consists of gravel on a bed of sand, and on the shore, the gravel is covered with bioderm. The benthic macroinvertebrate community consists of chironomids (30.52\%), Trichoptera (22.09\%), oligochaetes (21.29\%), Ephemeroptera (12.45\%), nematodes (9.63\%), gastropods (2.01\%, Physella acuta), beetles (2.01\%).

M14-171 m altitude, average width of the minor riverbed $75 \mathrm{~m}$ (max. $90 \mathrm{~m}$, min. $55 \mathrm{~m}$ ), the substrate consists of gravel on a bed of sand and mud; in the bed, there are depressions / pots, on the banks, there is a stripe of willows, and the benthic macroinvertebrate community is formed from Chironomidae (29.09\%), Trichoptera (25.45\%), Oligochaeta $(20.0 \%)$, Gastropoda (15.15\%, Physella acuta), Odonata $(10.31 \%)$.

The sediment (for the analysis of the amount of POPs) was collected manually from the surface of the riverbed substrate (at $50 \mathrm{~cm}$ water depth), with the help of a plastic vessel; the supernatant was removed, and $200 \mathrm{~g}$ of sediment were placed in the sample vessel, frozen in the field at $-20^{\circ} \mathrm{C}$, then stored in the laboratory at $-50{ }^{\circ} \mathrm{C}$.

The samples were collected manually: the insect larvae were washed to eliminate the sediment particles from their bodies, which can bring supplementary quantities of POPs, and frozen at $-20^{\circ} \mathrm{C}$ immediately after collection, then transported to the laboratory where they were stored at $-50^{\circ} \mathrm{C}$. The identification of insect larvae was performed at the order level, based on the morphological characters analyzed using an Olympus $(150 \times)$ stereomicroscope. Afterward, the samples were separated in Petri dishes that were washed beforehand with acetone:cyclohexane 1:1 and set to dry overnight in a desiccator at room temperature $\left(25^{\circ} \mathrm{C}\right)$ before extraction of POPs. Ephemeroptera and Trichoptera larvae of relatively homogenous size, for each group, were selected in order to avoid influencing the POP accumulation results. The biomass, expressed as dry weight, of the Ephemeroptera samples from which POPs were extracted is as follows: M1-0.8416 $\mathrm{g}$ (68 individuals), M2-0.7281 g (120 ind.), M3-1.1966 g (91 ind.), M4-0.2339 g (64 ind.), M6-0.2148 g (59 ind.), M7-0.1927 g (70 ind.), M11-0.1229 g (69 ind.), and M12-0.0915 g (73 ind.). In case of Trichoptera samples, the biomass, expressed as dry weight, is as follows: M1-0.8802 $\mathrm{g}$ (60 ind.), M2-0.2625 g (38 ind.), M3-0.2022 g (34 ind.), M4-0.4545 g (83 ind.), M6-0.1966 g (41 ind.), M11-2.0734 g (57 ind.), M12-0.7264 g (48 ind), and M14-1.1978 g (42 ind.).

\subsection{Reagents and Standards}

The solvents (acetone, cyclohexane, and ultrapure water) of HPLC grade purity were purchased from BioAqua (Târgu Mureş, Romania), and the $\mathrm{NaCl}(99.9 \%)$, green malachite $(99.9 \%)$, and sulfuric acid (96\%) were from Sigma-Aldrich. The PCB congeners $(28,29,31$, $47,52,56,66,74,99,101,105,110,112,114,118,128,136,137,138,141,149,151,153,156,157$, 170, 180, 183, 187, 189, 194, 196, 199, 206, 207, 209), DDT (o, p'-DDE, p, p'-DDE, o, p'DDD, p, p'-DDD, o, p'-DDT, p, p'-DDT), HCH ( $\alpha-\mathrm{HCH}, \beta-\mathrm{HCH}, \gamma-\mathrm{HCH}, \delta-\mathrm{HCH}, \varepsilon-\mathrm{HCH})$, chlordane (oxychlordane, trans-chlordane, cis-chlordane), HCB, and mirex standards were obtained from LGC Standards (Sibiu, Romania).

\subsection{Sample Preparation}

For the extraction of OCPs and PCBs from sediment and from benthos (insect larvae), we used a method involving 3:2 cyclohexane:acetone and ultrasonication [71]. Sediment was dried overnight in a desiccator, ground up with a mortar and pestle, and $5 \mathrm{~g}$ was used for extraction. In the case of benthos samples, the entire biomass was used for extraction. Internal standards (PCB 29, 112, 207) were added, and then the powder was extracted twice by ultrasonication using a Q500 sonicator (QSonica) (Newtown, CT, USA) and cyclohexane:acetone (3:2). The extract was separated from the sediment using an NF 800 R (Nüve) (Ankara, Turkey) centrifuge for $10 \mathrm{~min}$ at $2000 \mathrm{rpm}$; the supernatant (liquid extract) was transferred and calibrated to volume $(1 \mathrm{~mL})$ by evaporation. The extract was 
purified using clean sulfuric acid (96\%) (Sigma-Aldrich) (Bucureşti, Romania), and the resulting solution was calibrated to volume $(1 \mathrm{~mL})$ by evaporation. A volume of $0.5 \mathrm{~mL}$ was transferred to vials and stored for a maximum of two weeks before injection.

\subsection{Instrument Analysis}

The quantification of OCPs and PCBs was performed on a 7890 B (Agilent) (Bucureşti, Romania) gas chromatograph (GC) coupled to a 7010 A (Agilent) triple quadrupole mass spectrometry (MS) system (Bucureşti, Romania). The GC column was DB-5ms $60 \mathrm{~m}$, $0.25 \mathrm{~mm}, 0.25 \mu \mathrm{m}$ (Agilent) with helium as the carrier and quench gas, while nitrogen was used as the collision gas. The OCPs and PCBs were identified by running separate standards and observing the specific retention time and by collision-induced dissociation and observing the specific pattern of ions [72-74]. The inlet ran in splitless mode with $54.3 \mathrm{~mL} \mathrm{~min}{ }^{-1}$ carrier gas, the column carrier gas was set to $1.3 \mathrm{~mL} \mathrm{~min}^{-1}$, the quench gas was set to $2.25 \mathrm{~mL} \mathrm{~min}^{-1}$, and the collision gas was $1.5 \mathrm{~mL} \mathrm{~min}^{-1}$. The oven temperature was programmed to increase from $90^{\circ} \mathrm{C}$ with a 2 min hold to $180^{\circ} \mathrm{C}$ with a 2 min hold $\left(25^{\circ} \mathrm{C}^{- \text {min }}\right), 220^{\circ} \mathrm{C}$ with a 2 min hold $\left(1.5^{\circ} \mathrm{C}^{-\min }\right), 275^{\circ} \mathrm{C}$ with a 2 min hold $\left(3{ }^{\circ} \mathrm{C}^{- \text {min }}\right)$, and finally $300^{\circ} \mathrm{C}$ with a $4 \mathrm{~min}$ hold $\left(25^{\circ} \mathrm{C}^{-\min }\right)$.

\subsection{Quality Control}

The sediment samples were analyzed in three technical replicates in an analytical series that included six spiked samples (river sediment), with all the investigated analytes for recoveries, two blinds (river sediment), and four solvent blanks. The standard curve linearity $\left(\mathrm{R}^{2}\right)$ was above 0.993 for all analytes. The mean recovery percentage for sediment ranged from 81 to $119.5 \%$ for PCBs, 84.5 to $100.9 \%$ for DDTs, 81.8 to $100.4 \%$ for $\mathrm{HCHs}$, 111.8 to $114.7 \%$ for chlordane, $87.3 \%$ for $\mathrm{HCB}$, and $89.4 \%$ for mirex. The relative standard deviation values (RSD\%) were situated between 0.9 and $18.3 \%$ for PCBs, 2.7 and $12.8 \%$ for DDTs, 0.6 and $2.7 \%$ for $\mathrm{HCHs}, 2$ and $7.5 \%$ for chlordanes, $2.7 \%$ for $\mathrm{HCB}$, and $1.8 \%$ for mirex. No analytes were detected in the blanks. The data are reported as the arithmetic mean of the three technical replicates.

The benthos samples were separated by order into Ephemeroptera and Trichoptera and analyzed in an analytical series that included three spiked samples (Trichoptera samples), with all the investigated analytes for recoveries, one blind (Trichoptera sample), and four solvent blanks. The standard curve linearity $\left(R^{2}\right)$ was above 0.996 for all analytes. The mean recovery percentage for benthos ranged from 76.8 to $116.4 \%$ for PCBs, 70 to $83.2 \%$ for DDTs, 70.9 to $72 \%$ for HCHs, 96.8 to $99.4 \%$ for chlordane, $105.2 \%$ for $\mathrm{HCB}$, and $71.9 \%$ for mirex. The relative standard deviation values (RSD\%) were situated between 0.5 and $7.5 \%$ for PCBs, 2.3 and $5.8 \%$ for DDTs, 0.3 and $3.2 \%$ for HCHs, 1.4 and $6.5 \%$ for chlordane, $2.4 \%$ for $\mathrm{HCB}$, and $2.5 \%$ for mirex. No analytes were detected in the blanks.

All the reported concentrations were higher than the limit of quantitation (LOQ) [75].

\subsection{Data Analysis}

We investigated the ratios of $\mathrm{p}, \mathrm{p}^{\prime}-\mathrm{DDD} / \mathrm{p}, \mathrm{p}^{\prime}-\mathrm{DDE}[76]$ and $\left(\mathrm{p}, \mathrm{p}^{\prime}-\mathrm{DDE}+\mathrm{p}, \mathrm{p}^{\prime}-\mathrm{DDD}\right) / \mathrm{p}, \mathrm{p}^{\prime}-$ DDT [77] and their differences between the analyzed sample types; the ratios were calculated for the samples where all the compounds were present. We analyzed the data distribution by employing the Shapiro-Wilk normality test implemented in the base R 4.1.0 package. Afterward, a Kruskal-Wallis test was done in the base R 4.1.0 package, followed by a check of the empirical cumulative distribution functions (ECDF) of the investigated groups using the latticeExtra package in R. Based on the findings, the Conover-Iman multiple comparisons test with Bonferroni correction was implemented using the DescTools package in $\mathrm{R}$, taking into account the adjusted $p$ values $(p<0.05$ was considered significant). Spearman's rank correlation analysis was done in GraphPad Prism version $6.0(p<0.05$ was considered significant). The graphs were generated with the ggplot2 [78] package in R 4.1.0 and with GraphPad Prism version 6.0. The map (Figure 1) was generated using the QGIS 3.6 software [79] and the Natural Earth Data maps. 


\section{Results}

Out of the nine investigated sites, sufficient Trichoptera and Ephemeroptera individuals could be sampled from only eight of them.

Mirex and chlordanes were not found in any of the analyzed samples while HCB was found in only three Trichoptera samples (M11 with $0.63 \mathrm{ng} \mathrm{g}^{-1}$ dry weight, M12 with $0.89 \mathrm{ng} \mathrm{g}^{-1}$ dry weight, and M14 with $0.74 \mathrm{ng} \mathrm{g}^{-1}$ dry weight). The concentration of $\Sigma$ PCB ranged from 1.27 to $15.04 \mathrm{ng} \mathrm{g}^{-1}$ dry weight for sediment samples, from 33.06 to $66.51 \mathrm{ng} \mathrm{g}^{-1}$ dry weight for Trichoptera samples, and from 23.99 to $68 \mathrm{ng} \mathrm{g}^{-1}$ dry weight for Ephemeroptera samples (Table 1). In the case of $\Sigma \mathrm{HCH}$, the concentrations ranged from 0.19 to $40.02 \mathrm{ng} \mathrm{g}^{-1}$ dry weights for sediment samples, from 9.64 to $93.25 \mathrm{ng} \mathrm{g}^{-1}$ dry weight for Trichoptera samples, and from 59.65 to $239.39 \mathrm{ng} \mathrm{g}^{-1}$ dry weight for Ephemeroptera samples (Table 1). For $\Sigma$ DDT, the concentrations ranged from 1.21 to $25.95 \mathrm{ng} \mathrm{g}^{-1} \mathrm{dry}$ weight for sediment samples, from 26.73 to $57.17 \mathrm{ng} \mathrm{g}^{-1}$ dry weight for Trichoptera samples, and from 19.94 to $148.31 \mathrm{ng} \mathrm{g}^{-1}$ dry weight for Ephemeroptera samples (Table 1). We determined the frequency of detection of $\Sigma$ PCB to be $31.3 \%$ in sediment samples, $50 \%$ in Trichoptera samples, and $62.5 \%$ in Ephemeroptera samples. For $\Sigma \mathrm{HCH}$, the frequency of detection was 31.3\% in sediment samples, 50\% in Trichoptera samples, and 50\% in Ephemeroptera samples. For $\Sigma \mathrm{HCH}$, the frequency of detection was $31.3 \%$ in sediment samples, $75 \%$ in Trichoptera samples, and 100\% in Ephemeroptera samples for $\Sigma$ DDT (Table 1). For HCB, the frequency of detection was $37.5 \%$ for Trichoptera samples while the sediment and Ephemeroptera samples were not contaminated with HCB.

Table 1. Frequency of detection and concentration range of $\Sigma \mathrm{PCB}, \Sigma \mathrm{HCH}$, and $\Sigma$ DDT.

\begin{tabular}{|c|c|c|c|c|c|c|c|c|c|}
\hline \multirow{2}{*}{$\begin{array}{l}\text { Sample } \\
\text { POPs }\end{array}$} & \multicolumn{3}{|c|}{ Sediment } & \multicolumn{3}{|c|}{ Trichoptera } & \multicolumn{3}{|c|}{ Ephemeroptera } \\
\hline & $\Sigma P C B$ & $\Sigma \mathrm{HCH}$ & $\Sigma$ DDT & $\Sigma P C B$ & $\Sigma \mathrm{HCH}$ & $\Sigma D D T$ & ¿PCB & $\Sigma \mathrm{HCH}$ & $\Sigma$ DDT \\
\hline Min (ng g ${ }^{-1}$ dry weight) & 1.27 & 0.19 & 1.21 & 33.06 & 9.64 & 26.73 & 23.99 & 59.65 & 19.94 \\
\hline Max (ng g ${ }^{-1}$ dry weight) & 15.04 & 40.02 & 25.95 & 66.51 & 93.25 & 57.17 & 68.56 & 239.39 & 148.31 \\
\hline Mean (ng g ${ }^{-1}$ dry weight) & 5.01 & 11.39 & 11.23 & 46.03 & 33.31 & 43.27 & 41.21 & 131.83 & 91.86 \\
\hline Median (ng g ${ }^{-1}$ dry weight) & 2.20 & 2.34 & 10.29 & 42.27 & 15.18 & 47.71 & 35.17 & 114.14 & 114.86 \\
\hline Number of occurrences & 5 & 5 & 5 & 4 & 4 & 6 & 5 & 4 & 8 \\
\hline Frequency of detection * & $31.3 \%$ & $31.3 \%$ & $31.3 \%$ & $50.0 \%$ & $50.0 \%$ & $75.0 \%$ & $62.5 \%$ & $50.0 \%$ & $100.0 \%$ \\
\hline
\end{tabular}

The Spearman rank correlation coefficients between sediment and sampled benthos were the following: $-0.5(p>0.999)$ when comparing sediment to Trichoptera samples for $\Sigma$ PCB, $0.5(p>0.999)$ when comparing sediment to Trichoptera samples for $\Sigma \mathrm{HCH}$ and 1 ( $p=0.333)$ when comparing sediment to Ephemeroptera samples for $\Sigma \mathrm{HCH}$, and $0.5(p>0.999)$ when comparing sediment to Trichoptera samples for $\Sigma$ DDT and $0.9(p=0.083)$ when comparing sediment to Ephemeroptera samples for $\Sigma$ DDT.

The $\mathrm{p}, \mathrm{p}^{\prime}-\mathrm{DDD} / \mathrm{p}, \mathrm{p}^{\prime}-\mathrm{DDE}$ ratio was calculated for six of the nine sediment samples (with a minimum value of 0.377 and a maximum value of 2.672), for three of the eight Trichoptera samples $(0.219,0.174$, and 0.244$)$, and for two of the eight Ephemeroptera samples (0.465 and 0.526). The ( $\left.\mathrm{p}, \mathrm{p}^{\prime}-\mathrm{DDE}+\mathrm{p}, \mathrm{p}^{\prime}-\mathrm{DDD}\right) / \mathrm{p}, \mathrm{p}^{\prime}-\mathrm{DDT}$ ratio was calculated for five out of the nine sediment samples (with a minimum of 0.195 and a maximum of 1.694) and for three of the Trichoptera samples (3.360, 5.0393, and 10.115), while the ratio for Ephemeroptera samples was calculated for just one of the sampling sites (10.575).

In the case of $\Sigma D D T$, the most frequent compound detected in all the sample types was p,p'-DDE (sediment 55.6\%, Trichoptera 75\%, and Ephemeroptera 100\%). In the case of sediment samples, $\mathrm{p}, \mathrm{p}^{\prime}$-DDE was followed by $\mathrm{p}, \mathrm{p}^{\prime}$-DDD $(44.4 \%)$, and then on equal footing by o, $\mathrm{p}^{\prime}$-DDD, o, $\mathrm{p}^{\prime}$-DDT, and p, $\mathrm{p}^{\prime}$-DDT (33.3\%), while o, $\mathrm{p}^{\prime}$-DDE was not found in any sediment samples. For Trichoptera samples, $\mathrm{p}, \mathrm{p}^{\prime}$-DDE was followed by all the other compounds in equal frequency: $p, p^{\prime}-D D D, o, p^{\prime}-D D D, o, p^{\prime}-D D T, p, p^{\prime}-D D T$, and $\mathrm{o}, \mathrm{p}^{\prime}$-DDE (37.5\%). In the case of the Ephemeroptera samples, $\mathrm{p}, \mathrm{p}^{\prime}$-DDE was followed by $\mathrm{p}, \mathrm{p}^{\prime}-\mathrm{DDD}, \mathrm{o}, \mathrm{p}^{\prime}$-DDD, and o, $\mathrm{p}^{\prime}$-DDT with an equal detection frequency of $25 \%$ and then by $p, p^{\prime}-D D T(12,5 \%)$, while $o, p^{\prime}-D D E$ was not quantified in any of the sample sites. The median concentration decreased as follows for sediment samples: $p, p^{\prime}$-DDT > p, $p^{\prime}-D D D$ 
$>\mathrm{p}, \mathrm{p}^{\prime}$-DDE $>\mathrm{o}, \mathrm{p}^{\prime}$-DDD $>\mathrm{o}, \mathrm{p}^{\prime}$-DDT $>\mathrm{o}, \mathrm{p}^{\prime}$-DDE; in the following order for Trichoptera samples: $\mathrm{p}, \mathrm{p}^{\prime}-\mathrm{DDE}>\mathrm{p}, \mathrm{p}^{\prime}-\mathrm{DDT}>\mathrm{p}, \mathrm{p}^{\prime}$-DDD $>0, \mathrm{p}^{\prime}-\mathrm{DDT}>\mathrm{o}, \mathrm{p}^{\prime}-\mathrm{DDD}>\mathrm{o}, \mathrm{p}^{\prime}-\mathrm{DDE}$; and for Ephemeroptera samples in the following order: $p, p^{\prime}-D D E>p, p^{\prime}-D D D>0, p^{\prime}-D D D>$ $o, p^{\prime}-D D T>p, p^{\prime}-D D T>o, p^{\prime}$-DDE.

For $\Sigma$ PCB, the most frequent compound detected was PCB 28 in sediment and Trichoptera samples (sediment 33.3\% and Trichoptera 50.0\%) and PCB 66 in Ephemeroptera samples with $50.0 \%$ detection. In sediment samples, PCB 28 was followed by PCB31 and PCB66 (22.2\%) and then equally by PCB 52, PCB 56, PCB 149, PCB 170, and PCB 180 $(11.1 \%)$, while the rest of PCBs were not identified. For Trichoptera samples, PCB 28 was followed by PCB 31, PCB 47, РCB 52, PCB 56, РCB 66, РCB 74, РCB 99, РCB 101, РCB 110, PCB 118, PCB 138, PCB 149, PCB 151, PCB 153, and PCB 180 (37.5\%) then by PCB 170 and PCB 187 (25\%) and PCB 105, РCB 114, and PCB 141 (12.5\%) while the rest of compounds were not detected. In the case of the Ephemeroptera samples, PCB 66 was followed by PCB 28, PCB 56, and PCB 74 (37.5\%), by PCB 31 with 25\%, and then by PCB 52 and PCB 101 with an equal detection frequency of $12.5 \%$ while the other PCBs were not quantified in any of the sample sites. The median concentration decreased in the following order for sediment samples: PCB $28>$ PCB $31>$ PCB $66>$ PCB $56>$ PCB $180>$ PCB $52>$ PCB 170; in the following order for Trichoptera samples: PCB $28>$ PCB $66>$ PCB $31>$ PCB $52>$ PCB 56 $>$ PCB $74>$ PCB 153; and for Ephemeroptera samples in the following order: PCB $28>$ PCB $31>$ PCB $52>$ PCB $66>$ PCB $56>$ PCB $74>$ PCB 101.

In the case of $\Sigma \mathrm{HCH}$, the most frequent isomers detected were $\beta-\mathrm{HCH}$ and $\gamma-\mathrm{HCH}$ in sediment samples with a detection frequency of $22.2 \%$ and $\alpha-\mathrm{HCH}$ and $\beta-\mathrm{HCH}$ in Trichoptera and Ephemeroptera samples with an equal detection frequency of $50 \%$. In the case of sediment samples, $\beta-\mathrm{HCH}$ and $\gamma-\mathrm{HCH}$ were followed by $\alpha-\mathrm{HCH}(11.1 \%)$, while $\delta$ $\mathrm{HCH}$ and $\varepsilon-\mathrm{HCH}$ were not identified in any sediment samples. For Trichoptera samples, $\alpha-$ $\mathrm{HCH}$ and $\beta-\mathrm{HCH}$ were followed by $\gamma-\mathrm{HCH}$ and $\delta-\mathrm{HCH}$ with an equal detection frequency of $37.5 \%$ and then by $\varepsilon-\mathrm{HCH}(12.5 \%)$. In the case of Ephemeroptera samples, $\alpha-\mathrm{HCH}$ and $\beta-\mathrm{HCH}$ were followed by $\gamma-\mathrm{HCH}$ and $\delta-\mathrm{HCH}$ with an equal detection frequency of $25 \%$ and then by $\varepsilon-\mathrm{HCH}(12.5 \%)$. The median concentration decreased in the following order for sediment samples: $\alpha-\mathrm{HCH}>\beta-\mathrm{HCH}>\gamma-\mathrm{HCH}$; in the following order for Trichoptera samples: $\beta-\mathrm{HCH}>\alpha-\mathrm{HCH}>\gamma-\mathrm{HCH}>\delta-\mathrm{HCH}>\varepsilon-\mathrm{HCH}$; and for Ephemeroptera samples in the following order: $\alpha-\mathrm{HCH}>\beta-\mathrm{HCH}>\delta-\mathrm{HCH}>\gamma-\mathrm{HCH}>\varepsilon-\mathrm{HCH}$.

As can be seen in Figure 2, the concentration of $\Sigma \mathrm{PCB}, \Sigma \mathrm{HCH}$, and $\Sigma \mathrm{DDT}$ is higher in the invertebrate samples when it is detected than in the sediment samples in all the cases. For $\Sigma$ PCB and $\Sigma$ DDT, there are significantly higher concentrations detected in both Ephemeroptera and Trichoptera than in the sediment samples $(p<0.05)$. Meanwhile, for $\Sigma \mathrm{HCH}$ and $\Sigma \mathrm{DDT}$, only the Ephemeroptera group has a significantly higher concentration than the sediment samples, with the Trichoptera group having no difference in concentrations of POPs with regards to the other two analyzed groups (Figure 3).

In order to determine if the samples we analyzed (sediment, Trichoptera, and Ephemeroptera) all share the same source of contamination, we determined the ratios of $\mathrm{p}, \mathrm{p}^{\prime}-\mathrm{DDD} / \mathrm{p}, \mathrm{p}^{\prime}-$ DDE [76] and ( $\left.p, p^{\prime}-D D E+p, p^{\prime}-D D D\right) / p, p^{\prime}$-DDT [77] between sample types (Figure 4). 


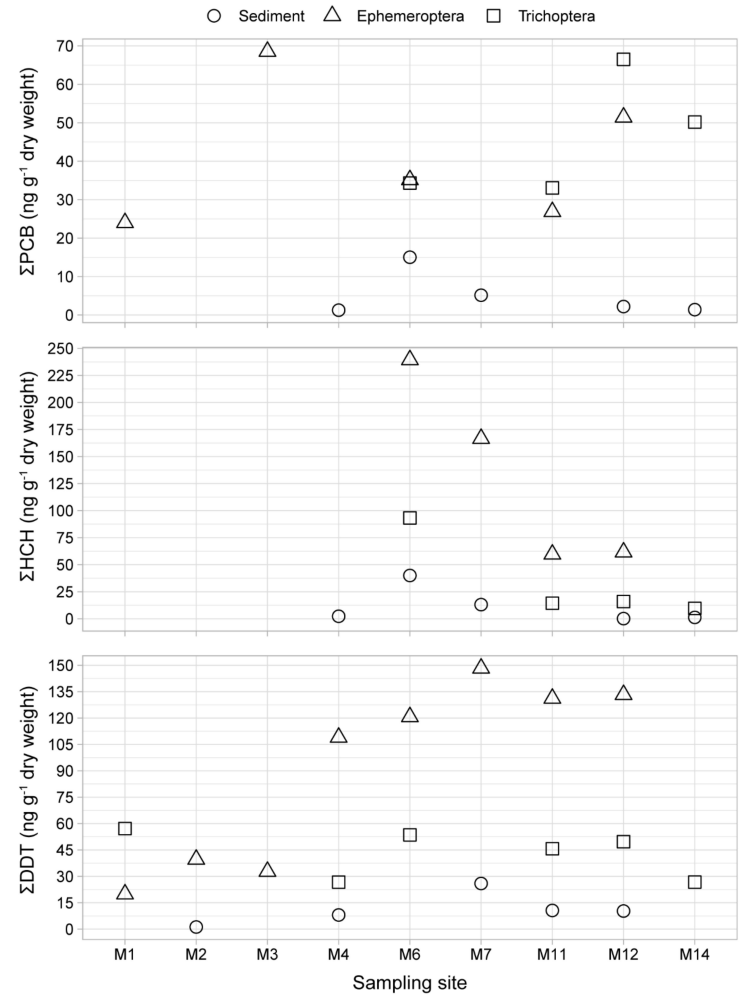

Figure 2. Concentration of $\Sigma \mathrm{PCB}, \Sigma \mathrm{HCH}$, and $\Sigma \mathrm{DDT}$ in sediment $(\bigcirc)$, Ephemeroptera $(\triangle)$, and Trichoptera $(\square)$ samples from the investigated sites.
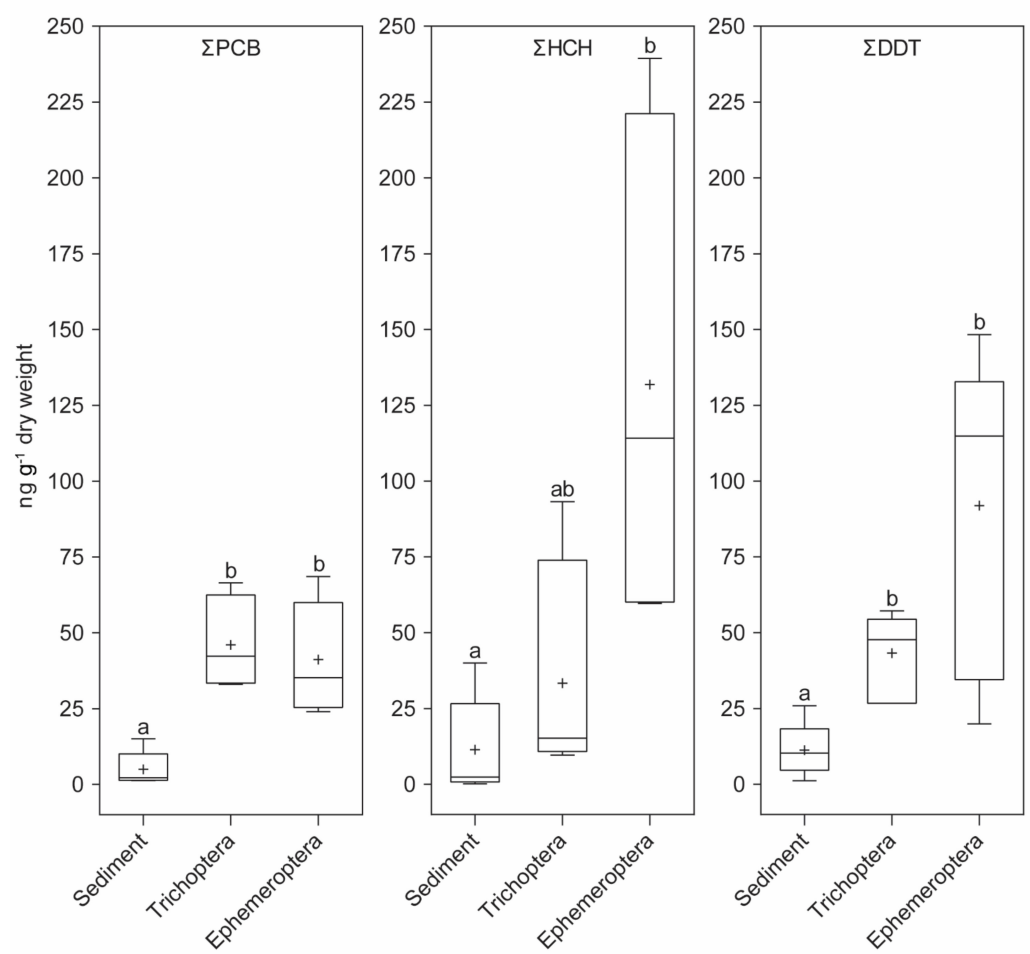

Figure 3. Significant differences in concentration between sediment, Trichoptera, and Ephemeroptera. Box plots with whiskers at the minimum and maximum values while the box is delimited by the 25th and 75th percentile with the median shown as a line and the mean as a plus sign. Different letters above the boxes indicate significant differences $(p<0.05)$. 

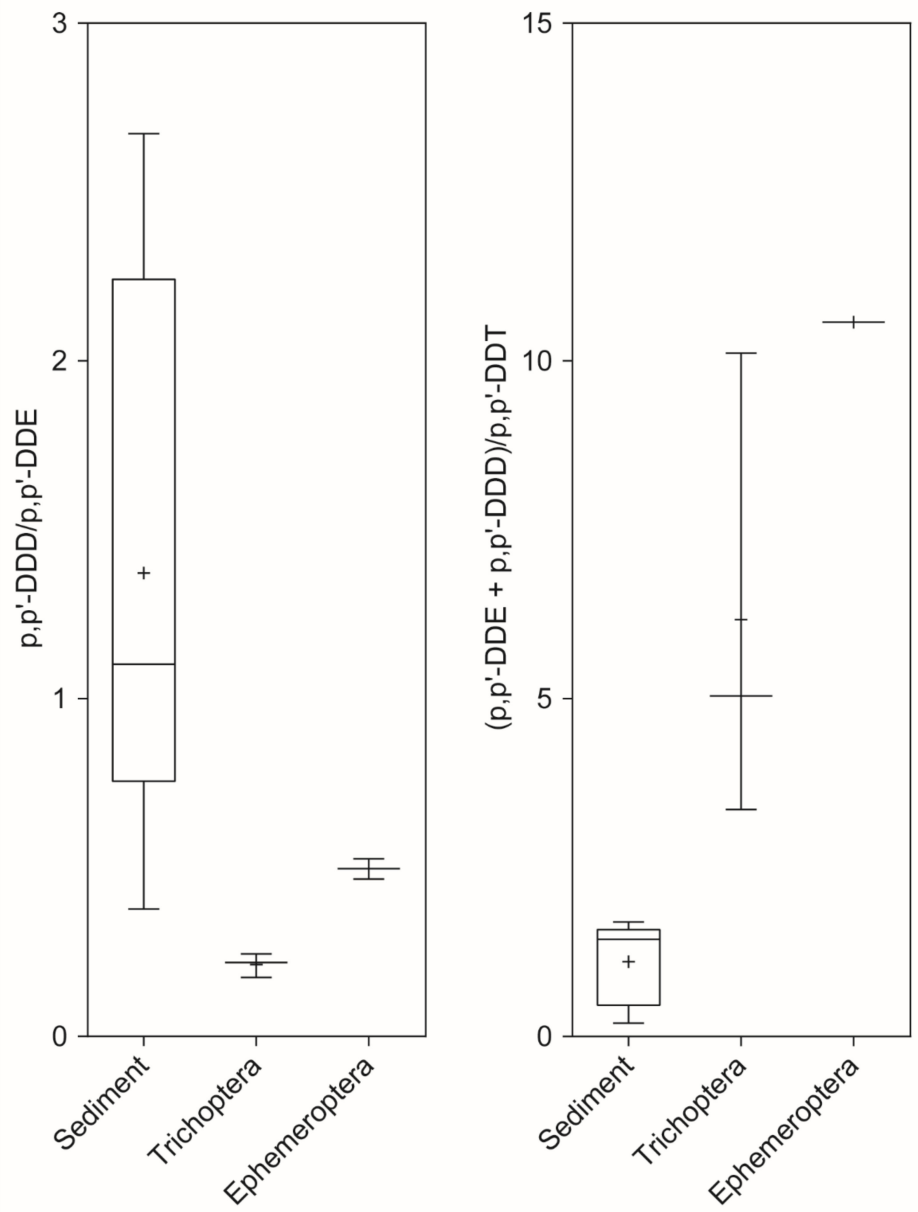

Figure 4. The $\mathrm{p}, \mathrm{p}^{\prime}-\mathrm{DDD} / \mathrm{p}, \mathrm{p}^{\prime}-\mathrm{DDE}$ and $\left(\mathrm{p}, \mathrm{p}^{\prime}-\mathrm{DDE}+\mathrm{p}, \mathrm{p}^{\prime}-\mathrm{DDD}\right) / \mathrm{p}, \mathrm{p}^{\prime}-\mathrm{DDT}$ ratio between sample types.

\section{Discussion}

The detection of Trichoptera and Ephemeroptera individuals in only eight out of nine sampling sites is due to the different habitats and habitat qualities encountered during this research along the Mureș River. Some of the sites where sediment was sampled were not populated with individuals from the Trichoptera (M7 site, Figure 1) or Ephemeroptera (M14 site, Figure 1) orders or the populations were not developed enough for a representative sample size.

Mirex was not directly used in Romania which is why we did not find its presence in sediment or benthos samples, and we could argue that the trans-boundary contamination with mirex is low in Romania.

The Spearman rank correlation results come as no surprise for the situation as few sites are compared, and between these sites, only some have concentrations of POPs in all three sampling categories investigated (sediment, Trichoptera larvae, and Ephemeroptera larvae). The ratio analysis showed (Figure 4) that there are too few samples that are contaminated with all three compounds of interest that could be used in a reliable test. Contrary to these results, the frequency of detection of $\Sigma$ DDT compounds shows a consistent decreasing trend from $\mathrm{p}, \mathrm{p}^{\prime}$-DDE to $\mathrm{p}, \mathrm{p}^{\prime}$-DDE that characterizes all of the sample types. In the case of $\Sigma \mathrm{PCB}$, the decreasing trend starts with PCB28 for all the investigated sample types and is similar between them while a similar situation is brought forth from the analysis of $\Sigma \mathrm{HCH}$ isomers which shows that $\beta-\mathrm{HCH}$ is most commonly found with a higher frequency than the rest (when not of equal frequency). From these last observations, we can propose that the contamination of sediment, Trichoptera, and Ephemeroptera samples is consistent with a single source of pollution, which could very well be the sediment that is considered by many as a reservoir for POPs [24,27]. 
The similar frequency of detection for the different compounds of DDT between sample types is an indication that there is no metabolization of a specific compound to the detriment of others and that if there is metabolization, it probably happens at a proportional rate to what is happening in the sediment samples. Another possibility could be due to a combination of the latter with a different bioaccumulation pattern of the investigated POPs which could very well be the situation for $\Sigma \mathrm{PCB}$ and $\Sigma \mathrm{HCH}$ in which the frequency of detection varies. When comparing the frequency of detection with the median concentrations, we see that the pollution with DDT in sediment shows recent contamination (higher concentration of $\mathrm{p}, \mathrm{p}^{\prime}$-DDT) while the median concentrations for benthos samples show contamination which is not so recent (higher concentration of $\mathrm{p}, \mathrm{p}^{\prime}$ DDE). This could be due to the recent sediment contamination which the benthos samples have not had time to bioaccumulate. Another possibility is that the benthos invertebrates (or lower trophic levels) break down DDT and become the source for metabolites in higher trophic levels [80]. This furthers the notion that there is a need for biomonitoring groups and that the analysis of sediment is still necessary and complementary to benthos [32,57].

One reason that the Trichoptera samples do not have a significantly higher concentration than the sediment samples could be the fact that some Trichoptera larvae create small houses that protect them from the surrounding sediment which could inhibit the capacity of bioaccumulation through direct contact [81]. The fact that the concentration of POPs is higher in the Ephemeroptera samples than in the sediment samples (Figure 1) coupled with the higher frequency of detection (Table 1) in both the Trichoptera and Ephemeroptera samples makes the latter group a better candidate for further analysis in determining the environment's POP contamination.

Our results support the idea of using Trichoptera and especially Ephemeroptera samples for biomonitoring purposes. Using benthos samples is usually a better decision than using other animals such as some fish because invertebrate larvae have restricted mobility [82] and are thus capable of better representing the study area. The use of invertebrate samples for biomonitoring has been proposed in the past for Laeonereis culveri in estuarine environments [83] and for benthos samples separated in FFGs [50]; therefore, we consider that the benthos samples we analyzed in this study are suitable for determining the contamination of POPs in the lotic environment.

In completion of many classification systems of monitoring parameters that are used in European countries, but not only, and up-to-date more uniform and continual classification proposals [84], we suggest the possibility of use of the sediment and Ephemeroptera and Trichoptera complex in pre-alert assessing and monitoring of the presence and level of the highly toxic POPs (OCPs and PCBs) in aquatic ecosystems.

\section{Conclusions}

In this study, we determined that the benthos samples have higher concentrations of POPs (OCPs and PCBs) than sediment samples. This, along with the fact that the frequency of detection for POPs is similar between the sample types makes the sedimentEphemeroptera-Trichoptera (SET) complex a suitable indicator of habitat contamination. The relatively short-medium-term gradient of pollution with POPs can be identified due to sediment and Ephemeroptera and Trichoptera assessment and monitoring, based on their short to medium to longer time of pollutant adsorption in sediments and bioaccumulation in Ephemeroptera and Trichoptera. This SET complex can be used to rapidly determine the appearance and longer time monitoring presence and concentration of POPs before they have time to bioaccumulate in edible organisms such as fish. Consequently, fish that live more than two years can be used in this respect as a much longer-term pollution indicator [36]. Therefore, the SET complex can constitute a pre-alert and alert group of indicators that reveal the presence and levels of POPs in aquatic systems before there is a threat to human food resources and to humans themselves.

Finally, it can be highlighted that the fact that the trophic niches created by these benthic organisms represent a compartment with an active functional-transfer role of POPs 
between the abiotic and higher-level trophic compartments ending on the human plates, the insect larvae representing, due to their relatively high biomass and turn-over, a very important taxonomic group for POP circulation in nature, together with sediments at an initial point and fish at the end of such analysis.

Author Contributions: Conceptualization, A.C.-B., A.B. and D.B.; methodology, A.C.-B. and A.B.; software, A.B.; formal analysis A.C.-B., A.B., C.-M.M. and D.B.; investigation, A.C.-B., A.B., C.-M.M. and D.B.; resources, A.C.-B.; data curation, A.B.; writing-original draft preparation, A.C.-B., A.B. and D.B.; writing-review and editing, A.C.-B., A.B. and D.B.; supervision, D.B.; funding acquisition, A.C.-B. All authors have read and agreed to the published version of the manuscript.

Funding: This research was funded by EEA Norway Grants and RO04 (SEE) funders of the ID 66243 SIDPOP project.

Institutional Review Board Statement: Ethical review and approval were waived for this study, since the biological material was formed by invertebrates. More than that these invertebrates are common, highly abundant in the environment, and of no national or international conservation value. Also, it must be added that no invertebrates were collected from protected areas.

Informed Consent Statement: This study did not involved humans.

Data Availability Statement: The data presented in this study are available on request from the corresponding author.

Acknowledgments: The authors acknowledge the EEA Norway Grants and RO04 (SEE) funders of the ID 66243 SIDPOP project in which these published data were obtained. For her support in the lab activities, the authors thank Teodora Maria Mărghidan. For her help in developing the method for quantification of POPs, the authors give thanks to Steluța Farcaș. Last but not the least, the authors acknowledge Daniel Baumgartel for his English language paper checking and suggestions.

Conflicts of Interest: The authors declare no conflict of interest.

\section{References}

1. Bănăduc, D.; Rey, S.; Trichkova, T.; Lenhardt, M.; Curtean-Bănăduc, A. The Lower Danube River-Danube Delta-North West Black Sea: A pivotal area of major interest for the past, present and future of its fish fauna-A short review. Sci. Total Environ. 2016, 545, 137-151. [CrossRef] [PubMed]

2. Bănăduc, D.; Joy, M.; Olosutean, H.; Afanasyev, S.; Curtean-Bănăduc, A. Natural and anthropogenic driving forces as key elements in the Lower Danube Basin-South-Eastern Carpathians-North-Western Black Sea coast area lakes, a broken stepping stones for fish in a climatic change scenario? Environ. Sci. Eur. 2020, 32, 1-14. [CrossRef]

3. Marić, S.; Stanković, D.; Wazenbök, J.; Šanda, R.; Erös, T.; Takács, A.; Specziár, A.; Sekulić, A.; Sekulić, N.; Bănăduc, D.; et al. Phylogeography and population genetics of the European mudminnow (Umbra krameri) with a time-calibrated phylogeny for the family Umbridae. Hydrobiologia. 2017, 792, 151-168. [CrossRef]

4. Cianfaglione, K.; Pedrotti, F. Italy in the Danube Geography: Territory, Landscape, Environment, Vegetation, Fauna, Culture, Human Management and Outlooks for the Future. In Human Impact on Danube Watershed Biodiversity in the XXI Century. Geobotany Studies (Basics, Methods and Case Studies); Bănăduc, D., Curtean-Bănăduc, A., Pedrotti, F., Cianfaglione, K., Akeroyd, J., Eds.; Springer: Cham, Switzerland, 2020; pp. 87-118.

5. Lenhardt, M.; Snederevac-Lalić, M.; Hegediš, A.; Skorić, S.; Cvijanović, G.; Višnjić-Jeftić, Ž.; Djikanović, V.; Jovičić, K.; Jaćimović, M.; Jarić, I. Human Impacts on Fish Fauna in the Danube River in Serbia: Current Status and Ecological Implications. In Human Impact on Danube Watershed Biodiversity in the XXI Century. Geobotany Studies (Basics, Methods and Case Studies); Bănăduc, D., Curtean-Bănăduc, A., Pedrotti, F., Cianfaglione, K., Akeroyd, J., Eds.; Springer: Cham, Switzerland, 2020; pp. 257-280.

6. Afanasyev, S.; Lyashenko, A.; Iarochevitch, A.; Lietytska, O.; Zorina-Sakharova, K.; Marushevska, O. Pressures and Impacts on Ecological Status of Surface Water Bodies in Ukrainian Part of the Danube River Basin. In Human Impact on Danube Watershed Biodiversity in the XXI Century. Geobotany Studies (Basics, Methods and Case Studies); Bănăduc, D., Curtean-Bănăduc, A., Pedrotti, F., Cianfaglione, K., Akeroyd, J., Eds.; Springer: Cham, Switzerland, 2020; pp. 327-359.

7. Teodorescu, D.; van den Kommer, M. Economic decline, fishing bans, and obstructive politics: Is there a future for small-scale fisheries in Romania's Danube Delta? In Small-Scale Fisheries in Europe: Status, Resilience and Governance. MARE Publication Series, 23th ed.; Pascual-Fernández, J., Pita, C., Bavinck, M., Eds.; Springer: Berlin/Heidelberg, Germany, 2020.

8. Curtean-Bănăduc, A.; Didenko, A.; Guti, G.; Bănăduc, D. Telestes souffia (Risso, 1827) species conservation at the eastern limit of range-Vişeu River basin, Romania. Appl. Ecol. Environ. Res. 2018, 16, 91-303. [CrossRef] 
9. Curtean-Bănăduc, A.; Marić, S.; Gabor, G.; Didenko, A.Ş.; Rey Planellas, S.; Bănăduc, D. Hucho hucho (Linnaeus, 1758): Last natural viable population in the Eastern Carpathians-conservation elements. Turk. Zool. Derg. 2019, 43, 215-223. [CrossRef]

10. Voicu, R.; Radecki-Pawlik, A.; Voicu, L.; Urbani, J.D.; Bănăduc, D. Innovative on-site adapted system for fish migration with flow divider and glass collector basin. Transylv. Rev. Syst. Ecol. Res. 2020, 22, 81-98.

11. Curtean-Bănăduc, A.; Bănăduc, D. The Transylvanian Water Tower through history. Danub. News 2015, 32, 1-4.

12. Curtean-Bănăduc, A.; Bănăduc, D.; Bucşa, C. Watersheds Management (Transylvania/Romania): Implications, risks, solutions, Strategies to enhance environmental Security in transition countries. In NATO Science for Peace and Security Series C-Environmental Security; Springer: Berlin/Heidelberg, Germany, 2007; pp. 225-238.

13. Bănăduc, D.; Curtean-Bănăduc, A.; Cianfaglione, K.; Akeroyd, J.R.; Cioca, L.-I. Proposed environmental risk management elements in a Carpathian valley basin, within the Roşia Montană European historical mining area. Int. J. Environ. Res. Public Health 2021, 18, 4565. [CrossRef] [PubMed]

14. Costea, G.; Push, M.T.; Bănăduc, D.; Cosmoiu, D.; Curtean-Bănăduc, A. A review of hydropower plants in Romania: Distribution, current knowledge, and their effects on fish in headwater streams. Renew. Sust. Energy Rev. 2021, 54, 111003.

15. Burcea, A.; Boeraş, I.; Mihuţ, C.-M.; Bănăduc, D.; Matei, C.; Curtean-Bănăduc, A. Adding the Mureş River Basin (Transylvania, Romania) to the list of hotspots with high contamination with pharmaceuticals. Sustainability 2020, 12, 10197. [CrossRef]

16. La Merrill, M.; Emond, C.; Kim, M.J.; Antignac, J.-P.; Le Bizec, B.; Clément, K.; Birnbaum, L.S.; Barouk, R. Toxicological function of adipose tissue: Focus on persistent organic pollutants. Environ. Health Perspect 2013, 121, 162-169. [CrossRef] [PubMed]

17. Hung, H.; Katsoyiannis, A.A.; Brorström-Lunden, E.; Olaffsdottir, K.; Aas, W.; Breivik, K.; Bohlin-Nizzetto, P.; Sigurdsson, A.; Hakola, H.; Bossi, R.; et al. Temporal trends of persistent organic pollutants (POPs) in arctic air: 20 years of monitoring under the Arctic Monitoring and Assessment Programme (AMAP). Environ. Pollut. 2016, 217, 52-61. [CrossRef]

18. Stockholm Convention 2001. Available online: http:/ / chm.pops.int/ (accessed on 26 August 2019).

19. Ritter, L.; Solomon, K.R.; Forget, J.; Stemeroff, M.; O'leary, C. A review of selected persistent organic pollutants. In International Programme on Chemical Safety (IPCS). PCS/95.39; World Health Organization: Geneva, Switzerland, 1995; Volume 65, p. 66.

20. Gupta, V.K.; Ali, I. Environmental Water: Advances in Treatment, Remediation and Recycling; Newnes: Amsterdam, The Netherlands, 2012.

21. Köhler, H.R.; Triebskorn, R. Wildlife ecotoxicology of pesticides: Can we track effects to the population level and beyond? Science 2013, 341, 759-765. [CrossRef] [PubMed]

22. Fernández, P.; Grimalt, J.O. On the global distribution of persistent organic pollutants. Chimia 2003, 57, 514-521. [CrossRef]

23. Montuori, P.; Cirillo, T.; Fasano, E.; Nardone, A.; Esposito, F.; Triassi, M. Spatial distribution and partitioning of polychlorinated biphenyl and organochlorine pesticide in water and sediment from Sarno River and Estuary, Southern Italy. Environ. Sci. Pollut. Res. 2014, 21, 5023-5035. [CrossRef] [PubMed]

24. Sakan, S.; Ostojić, B.; Đorđević, D. Persistent organic pollutants (POPs) in sediments from river and artificial lakes in Serbia. J. Geochem. Explor. 2017, 180, 91-100. [CrossRef]

25. Behroz, R.D.; Esmaili-Sari, A.; Chakraborty, P. Distribution and Eco-toxicological risk assessment of legacy persistent organic pollutants in surface water of Talar, Babolrood and Haraz rivers. Water 2020, 12, 3104. [CrossRef]

26. Chicea, D.; Rei, S.M. Light scattering for monitoring the size of the suspended particles in wastewater. Transylv. Rev. Syst. Ecol. Res. 2019, 21, 1-10.

27. Liu, M.; Cheng, S.; Ou, D.; Yang, Y.; Liu, H.; Hou, L.; Gao, L.; Xu, S. Organochlorine pesticides in surface sediments and suspended particulate matters from the Yangtze estuary, China. Environ. Pollut. 2008, 156, 168-173. [CrossRef]

28. Cai, M.; Qiu, C.; Shen, Y.; Cai, M.; Huang, S.; Qian, B.; Sun, J.; Liu, X. Concentration and distribution of 17 organochlorine pesticides (OCPs) in seawater from the Japan Sea northward to the Arctic Ocean. Sci. China Chem. 2010, 53, 1033-1047. [CrossRef]

29. Salem, D.M.A.; Khaled, A.; El Nemr, A. Assessment of pesticides and polychlorinated biphenyls (PCBs) in sediments of the Egyptian Mediterranean Coast. Egypt. J. Aquat. Res. 2013, 39, 141-152. [CrossRef]

30. Zhang, Z.L.; Hong, H.S.; Zhou, J.L.; Huang, J.; Yu, G. Fate and assessment of persistent organic pollutants in water and sediment from Minjiang River Estuary, Southeast China. Chemosphere 2003, 52, 1423-1430. [CrossRef]

31. Bettinetti, R.; Giarei, C.; Provini, A. Chemical analysis and sediment toxicity bioassays to assess the contamination of the River Lambro (Northern Italy). Arch. Environ. Contam. Toxicol. 2003, 45, 72-78. [CrossRef] [PubMed]

32. Barhoumi, B.; Beldean-Galea, M.S.; Al-Rawabdeh, A.M.; Roba, C.; Martonos, I.M.; Bălc, R.; Kahlaoui, M.; Touil, S.; Tedetti, M.; Driss, M.R.; et al. Occurrence, distribution and ecological risk of trace metals and organic pollutants in surface sediments from a Southeastern European river (Someşu Mic River, Romania). Sci. Total Environ. 2019, 660, 660-676. [CrossRef] [PubMed]

33. Kelly, B.C.; Ikonomou, M.G.; Blair, J.D.; Morin, A.E.; Gobas, F.A. Food web-specific biomagnification of persistent organic pollutants. Science 2007, 317, 236-239. [CrossRef] [PubMed]

34. Alava, J.J.; Cheung, W.W.; Ross, P.S.; Sumaila, U.R. Climate change-contaminant interactions in marine food webs: Toward a conceptual framework. Glob. Chang. Biol. 2017, 23, 3984-4001. [CrossRef]

35. Joy, M.; Death, R.G. Biological assessment of rivers in the Manawatu-Wanganui region of New Zealand using a predictive macroinvertebrate model. N. Z. J. Mar. Freshw. Res. 2003, 37, 367-379. [CrossRef]

36. Curtean-Bănăduc, A.; Burcea, A.; Mihuţ, C.-M.; Berg, V.; Lyche, J.L.; Bănăduc, D. Bioaccumulation of persistent organic pollutants in the gonads of Barbus barbus (Linnaeus, 1758). Ecotox. Environ. Saf. 2020, 201, 110852. [CrossRef] [PubMed] 
37. Liu, Y.; Luo, X.J.; Huang, L.Q.; Yu, L.H.; Mai, B.X. Bioaccumulation of persistent halogenated organic pollutants in insects: Common alterations to the pollutant pattern for different insects during metamorphosis. Environ. Sci. Technol. 2018, 52, $5145-5153$. [CrossRef]

38. Vos, J.G.; Dybing, E.; Greim, H.A.; Ladefoged, O.; Lambré, C.; Tarazona, J.V.; Brandt, I.; Vethaak, A.D. Health effects of endocrine-disrupting chemicals on wildlife, with special reference to the European situation. Crit. Rev. Toxicol. 2000, 30, 71-133. [CrossRef]

39. Adeola, F.O. Boon or bane? The environmental and health impacts of persistent organic pollutants (POPs). Hum. Ecol. Rev. 2004, $11,27-35$.

40. Vasseur, P.; Cossu-Leguille, C. Linking molecular interactions to consequent effects of persistent organic pollutants (POPs) upon populations. Chemosphere 2006, 62, 1033-1042. [CrossRef] [PubMed]

41. Qing Li, Q.; Loganath, A.; Seng Chong, Y.; Tan, J.; Philip Obbard, J. Persistent organic pollutants and adverse health effects in humans. J. Toxicol. Environ. Health A 2006, 69, 1987-2005. [CrossRef]

42. Alharbi, O.M.; Khattab, R.A.; Ali, I. Health and environmental effects of persistent organic pollutants. J. Mol. Liq. 2018, 263, 442-453. [CrossRef]

43. Pereira, L.R.; Cabette, H.S.; Juen, L. Trichoptera as bioindicators of habitat integrity in the Pindaíba river basin, Mato Grosso (Central Brazil). In Annales de Limnologie-International Journal of Limnology; EDP Sciences: Les Ulis, France, 2012; Volume 48, pp. 295-302.

44. Curtean-Bănăduc, A.; Olosutean, H.; Bănăduc, D. Influence of environmental variables on the structure and diversity of Ephemeran communities: A case study of the Timiş River, Romania. Acta Zool. Bulg. 2016, 68, 215-224.

45. Pastorino, P.; Bertoli, M.; Squadrone, S.; Brizio, P.; Piazza, G.; Noser, A.G.O.; Prearo, M.; Abete, M.C.; Pizzul, E. Detection of trace elements in freshwater macrobenthic invertebrates of different functional feeding guilds: A case study in Northeast Italy. Ecohydrol. Hydrobiol. 2019, 19, 428-440. [CrossRef]

46. Pastorino, P.; Brizio, P.; Abete, M.C.; Bertoli, M.; Noser, A.G.O.; Piazza, G.; Prearo, M.; Elia, A.C.; Pizzul, E.; Squadrone, S. Macrobenthic invertebrates as tracers of rare earth elements in freshwater watercourses. Sci. Total Environ. 2020, 698, 134282. [CrossRef]

47. Parker, T.J.; Haswell, W.A. Textbook of Zoology; Macmillan International Higher Education: London, UK, 1967.

48. Rosenberg, D.M.; Danks, H.V.; Lehmkuhl, D.M. Importance of insects in environmental impact assessment. Environ. Manag. 1986, 10, 773-783. [CrossRef]

49. Baxter, C.V.; Fausch, K.D.; Carl Saunders, W. Tangled webs: Reciprocal flows of invertebrate prey link streams and riparian zones. Freshw. Biol. 2005, 50, 201-220. [CrossRef]

50. Pastorino, P.; Zaccaroni, A.; Doretto, A.; Falasco, E.; Silvi, M.; Dondo, A.; Elia, A.C.; Prearo, M.; Bona, F. Functional Feeding Groups of Aquatic Insects Influence Trace Element Accumulation: Findings for Filterers, Scrapers and Predators from the Po Basin. Biology 2020, 9, 288. [CrossRef]

51. Holzenthal, R.W.; Thomson, R.E.; Ríos-Touma, B. Order Trichoptera. In Thorp and Covich's Freshwater Invertebrates; Academic Press: Cambridge, MA, USA, 2015; pp. 965-1002.

52. Morse, J.C. Trichoptera (caddisflies). In Encyclopedia of Insects; Academic Press: Cambridge, MA, USA, 2009; pp. 1015-1020.

53. Hubbard, M.D.; Peters, W.L. Environmental Requirements and Pollution Tolerance of Ephemeroptera; Environmental Protection Agency, Office of Research and Development, Environmental Monitoring and Support Laboratory: Washington, DC, USA, 1978.

54. Bauernfeind, E.; Moog, O. Mayflies (Insecta: Ephemeroptera) and the assessment of ecological integrity: A methodological approach. In Assessing the Ecological Integrity of Running Waters; Springer: Dordrecht, The Netherlands, 2000; pp. 71-83.

55. Barber-James, H.M.; Gattolliat, J.L.; Sartori, M.; Hubbard, M.D. Global diversity of mayflies (Ephemeroptera, Insecta) in freshwater. In Freshwater Animal Diversity Assessment; Springer: Dordrecht, The Netherlands, 2007; pp. 339-350.

56. Edmunds, G.F., Jr.; Jensen, S.L.; Berner, L. (Eds.) The Mayflies of North and Central America; U of Minnesota Press: Minneapolis, MN, USA, 1976.

57. Bauernfeind, E.; Soldan, T. The Mayflies of Europe (Ephemeroptera); Brill: Leiden, The Netherlands, 2012.

58. Mwanamoki, P.M.; Devarajan, N.; Thevenon, F.; Birane, N.; De Alencastro, L.F.; Grandjean, D.; Mpiana, P.T.; Prabakar, K.; Mubedi, J.I.; Kabele, C.G.; et al. Trace metals and persistent organic pollutants in sediments from river-reservoir systems in Democratic Republic of Congo (DRC): Spatial distribution and potential ecotoxicological effects. Chemosphere 2014, 111, 485-492. [CrossRef] [PubMed]

59. Berg, V.; Lyche, J.L.; Karlsson, C.; Stavik, B.; Nourizadeh-Lillabadi, R.; Hårdnes, N.; Skaare, J.U.; Alestrøm, P.; Lie, E.; Ropstad, E. Accumulation and effects of natural mixtures of persistent organic pollutants (POP) in zebrafish after two generations of exposure. J. Toxicol. Environ. Health A 2011, 74, 407-423. [CrossRef]

60. Berg, V.; Kraugerud, M.; Nourizadeh-Lillabadi, R.; Olsvik, P.A.; Skåre, J.U.; Alestrom, P.; Ropstad, E.; Zimmer, K.; Lyche, J.L. Endocrine effects of real-life mixtures of persistent organic pollutants (POP) in experimental models and wild fish. J. Toxicol. Environ. Health Part A 2016, 79, 538-548. [CrossRef] [PubMed]

61. Kraugerud, M.; Doughty, R.W.; Lyche, J.L.; Berg, V.; Tremoen, N.H.; Alestrøm, P.; Alexandersen, M.; Ropstad, E. Natural mixtures of persistent organic pollutants (POPs) suppress ovarian development, liver vitellogenin immunostaining and hepatocyte proliferation in female zebrafish (Danio rerio). Aquat. Toxicol. 2012, 116, 16-23. [CrossRef] 
62. Lyche, J.L.; Nourizadeh-Lillabadi, R.; Almaas, C.; Stavik, B.; Berg, V.; Skåre, J.U.; Alestrøm, P.; Ropstad, E. Natural mixtures of persistent organic pollutants (POP) increase weight gain, advance puberty, and induce changes in gene expression associated with steroid hormones and obesity in female zebrafish. J. Toxicol. Environ. Health A 2010, 73, 1032-1057. [CrossRef] [PubMed]

63. Lyche, J.L.; Nourizadeh-Lillabadi, R.; Karlsson, C.; Stavik, B.; Berg, V.; Skaare, J.U.; Alestrøm, P.; Ropstad, E. Natural mixtures of POPs affected body weight gain and induced transcription of genes involved in weight regulation and insulin signalling. Aquat. Toxicol. 2011, 102, 197-204. [CrossRef] [PubMed]

64. Lyche, J.L.; Grześ, I.M.; Karlsson, C.; Nourizadeh-Lillabadi, R.; Berg, V.; Kristoffersen, A.B.; Skåre, J.U.; Alestrøm, P.; Ropstad, E. Parental exposure to natural mixtures of POPs reduced embryo production and altered gene transcription in zebrafish embryos. Aquat. Toxicol. 2013, 126, 424-434. [CrossRef] [PubMed]

65. Nourizadeh-Lillabadi, R.; Lyche, J.L.; Almaas, C.; Stavik, B.; Moe, S.J.; Alexandersen, M.; Berg, V.; Jakobsen, K.S.; Stenseth, N.C.; Skaare, J.U.; et al. Transcriptional regulation in liver and testis associated with developmental and reproductive effects in male zebrafish exposed to natural mixtures of persistent organic pollutants (POP). J. Toxicol. Environ. Health A 2009, 72, 112-130. [CrossRef]

66. Antipa, G. Fauna Ihtiologică a României; Academia Romana, Publicatiunile Fondului Vasile Adamachi: Bucureşti, Romania, 1909; p. 294.

67. Băcescu, M. Peştii, Aşa Cum îi Vede Țăranul Pescar Român, Institutul de Cercetări Piscicole al României, Monographia, 3th ed.; Monitorul Oficial şi Imprimeriile Statului Imprimeria Naţională Bucureşti: Bucureşti, Romania, 1946; p. 218.

68. Bănărescu, P.M. Pisces-Osteichthyes, 13th ed.; Fauna, R.P., Acad, R.P.R., Eds.; Acad, R.P.R.: Bucureşti, Romania, 1964; Volume XIII, p. 959.

69. Posea, G. Enciclopedia Geografică a României; Ştiinţifică şi Enciclopedică: Bucureşti, Romania, 1982; p. 262.

70. Curtean-Bănăduc, A.; Bănăduc, D.; Burcea, A.; Berg, V.; Lyche, J.L.; Gheorghe, L.M. Persistent organic pollutants in Mureş watershed. In The Impact of Persistent Organic Pollutants on Freshwater Ecosystems and Human Health; Curtean-Bănăduc, A., Ed.; Editura Universității Lucian Blaga: Sibiu, Romania, 2016; pp. 119-154.

71. Collings, A.F.; Farmer, A.D.; Gwan, P.B.; Pintos, A.S.; Leo, C.J. Processing contaminated soils and sediments by high power ultrasound. Miner. Eng. 2006, 19, 450-453. [CrossRef]

72. Wylie, P.L.; Meng, C.K. A Method for the Trace Analysis of 175 Pesticides Using the Agilent Triple Quadrupole GC/MS/MS; Agilent Technologies Publication: Santa Clara, CA, USA, 2009; Volume 92, pp. 123-137.

73. Mariappan, M.; Kumar, H.; Kandaswamy, C.; Kulkurni, S.; Determination of Multi-Pesticide Residues in Red Chili Powder Using QuEChERS and the Agilent 7000 Series Triple Quadrupole GC/MS System. Application Note. Food Safety. 5991-4193EN. 2014, p. 10. Available online: http://www.ingenieria-analitica.com/downloads/dl/file/id/3128/product/360/determination_ of_multi_pesticide_residues_in_red_chili_powder_using_quechers_and_the_agilent_7000_series_triple_quadrupole_gc_ms_ system.pdf (accessed on 22 February 2021).

74. Ciscato, C.; Barbosa, C.; Gebara, A. Analysis of Pesticide Residues in Mango by GC/MS/MS with Bond Elut QuEChERS EN Kits; Agilent Technologies Publication: Santa Clara, CA, USA, 2015.

75. Ripp, J. PUBL-TS-056-96 Laboratory Certification Program. In Analytical Detection Limit Guidance E Amp. Laboratory Guide for Determining Method Detection Limits; Wisconsin Department of Natural Resources: Madison, WI, USA, 1996; p. 24.

76. Pinkney, A.E.; McGowan, P.C. Use of the p, p'-DDD: P, p'-DDE concentration ratio to trace contaminant migration from a hazardous waste site. Environ. Monit. Assess. 2006, 120, 559-574. [CrossRef]

77. Zhang, C.; Liu, L.; Ma, Y.; Li, F. Using isomeric and metabolic ratios of DDT to identify the sources and fate of DDT in Chinese agricultural topsoil. Environ. Sci. Technol. 2018, 52, 1990-1996. [CrossRef]

78. Wickham, H. ggplot2: Elegant Graphics for Data Analysis; Springer: New York, NY, USA, 2016; Available online: https://ggplot2 .tidyverse.org (accessed on 22 February 2021).

79. QGIS Development Team, QGIS Geographic Information System. Open Source Geospatial Foundation. 2019. Available online: http:/ / qgis.org (accessed on 11 August 2020).

80. Ren, J.; Wang, X.; Wang, C.; Gong, P.; Wang, X.; Yao, T. Biomagnification of persistent organic pollutants along a high-altitude aquatic food chain in the Tibetan Plateau: Processes and mechanisms. Environ. Pollut. 2017, 220, 636-643. [CrossRef]

81. Ferry, E.E.; Hopkins, G.R.; Stokes, A.N.; Mohammadi, S.; Brodie, E.D., Jr.; Gall, B.G. Do all portable cases constructed by caddisfly larvae function in defense? J. Insect Sci. 2013, 13, 5. [CrossRef] [PubMed]

82. Parmar, T.K.; Rawtani, D.; Agrawal, Y.K. Bioindicators: The natural indicator of environmental pollution. Front. Life Sci. 2016, 9 , 110-118. [CrossRef]

83. Díaz-Jaramillo, M.; Laitano, M.V.; Gonzalez, M.; Miglioranza, K.S.B. Spatio-temporal trends and body size differences of OCPs and PCBs in Laeonereis culveri (Polychaeta: Nereididae) from Southwest Atlantic estuaries. Mar. Pollut. Bull. 2018, 136, 107-113. [CrossRef] [PubMed]

84. Barinova, S. On the Classification of Water Quality from an Ecological Point of View. IJESNR 2017, 2, 1-8. [CrossRef] 